\title{
Characterization of Biosensors Based on Recombinant Glutamate Oxidase: Comparison of Crosslinking Agents in Terms of Enzyme Loading and Efficiency Parameters
}

\author{
Rochelle Ford, Susan J. Quinn and Robert D. O'Neill * \\ UCD School of Chemistry, University College Dublin, Belfield, Dublin D04 N2E5, Ireland; \\ Rochelle.Ford@ucdconnect.ie (R.F.); Susan.Quinn@ucd.ie (S.J.Q.) \\ * Correspondence: Robert.ONeill@ucd.ie; Tel.: +353-1-716-2314 \\ Academic Editor: Alexander Star \\ Received: 28 July 2016; Accepted: 18 September 2016; Published: 23 September 2016
}

\begin{abstract}
Amperometric L-glutamate (Glu) biosensors, based on both wild-type and a recombinant form of L-glutamate oxidase (GluOx), were designed and characterized in terms of enzyme-kinetic, sensitivity and stability parameters in attempts to fabricate a real-time Glu monitoring device suitable for future long-term detection of this amino acid in biological and other complex media. A comparison of the enzyme from these two sources showed that they were similar in terms of biosensor performance. Optimization of the loading of the polycationic stabilization agent, polyethyleneimine (PEI), was established before investigating a range of crosslinking agents under different conditions: glutaraldehyde (GA), polyethylene glycol (PEG), and polyethylene glycol diglycidyl ether (PEGDE). Whereas PEI-free biosensor designs lost most of their meager Glu sensitivity after one or two days, configurations with a 2:5 ratio of dip-evaporation applications of PEI(1\%):GluOx(400 U/mL) displayed a 20-fold increase in their initial sensitivity, and a decay half-life extended to 10 days. All the crosslinkers studied had no effect on initial Glu sensitivity, but enhanced biosensor stability, provided the crosslinking procedure was carried out under well-defined conditions. The resulting biosensor design based on the recombinant enzyme deposited on a permselective layer of poly-(ortho-phenylenediamine), $\mathrm{PoPD} / \mathrm{PEI}_{2} / \mathrm{GluOx}_{5} / \mathrm{PEGDE}$, displayed good sensitivity (LOD $<0.2 \mu \mathrm{M})$, response time $\left(t_{90 \%}<1 \mathrm{~s}\right)$ and stability over a 90 -day period, making it an attractive candidate for future long-term monitoring of Glu concentration dynamics in complex media.
\end{abstract}

Keywords: glutamate biosensor stability; biomedical applications; amperometry; surface enzyme loading and affinity; permselective polymer; poly(ortho-phenylenediamine)

\section{Introduction}

Research into the design and characterization of biosensors for L-glutamate (Glu) is currently a significant area of study due to the important roles this amino acid plays in the food industry [1-3] and as a neurotransmitter $[4,5]$. In the latter context, Glu is the most widespread excitatory neurotransmitter in the mammalian brain, and has been implicated in a number of psychiatric and neurological disorders, such as schizophrenia, Parkinson's disease, and stroke [6-10]. However, there are many challenges associated with exploring the roles of brain Glu, using different in vivo monitoring techniques. For example, high sensitivity is required because of the low baseline concentration of Glu in extracellular fluids (ECF) of the intact living brain (i.e., in vivo), estimated in the range of $1-10 \mu \mathrm{M}$ which can depend on a wide variety of conditions, such as the anatomical location of the implanted probe and the level of anaesthesia $[8,9,11-13]$. A wider range of brain Glu concentration 
values have been reported under more extreme conditions. For example, for slices of excised brain (i.e., in vitro) levels as low as $25 \mathrm{nM}$ have been estimated [14]. In contrast, values of hundreds of micromolar have been detected in vivo when baseline levels of $\sim 2 \mu \mathrm{M}$ were increased by two orders of magnitude following traumatic brain injury [15].

Both invasive and non-invasive technologies have been developed for neurochemical monitoring in vivo. While the latter have many attractions associated with the absence of tissue disruption, and some are sensitive enough to detect behavior-correlated neurotransmitter release [16], they are currently not suitable for chronic studies. The two main approaches to measuring long-term brain Glu levels in vivo are microdialysis [17,18] and electrochemical biosensors [13,19,20]. A temporal resolution of $\sim 1 \mathrm{~min}$ has been achieved using microdialysis for the detection of neurotransmitters such as serotonin [21] and Glu [22]. In contrast, biosensors represent a more useful approach for monitoring fast concentration dynamics of Glu (sub-second scale) due to the higher spatial and temporal resolution achievable with implantable amperometric biosensors. Moreover, long-term in vivo electrochemistry (LIVE) has been demonstrated in the case of sensors, such as carbon-fiber or carbon-paste electrodes for monitoring neurotransmitters [23] and their metabolites [24] over periods of months. However, the inherent complexity of biosensors, incorporating a range of components (including enzymes, permselective membranes and enzyme stabilizers), aggravates the challenge of their long-term stability in biological tissues and other complex media [24-26]. In this work, a biosensor was designed for the detection of Glu, with an emphasis on sensitivity and stability, based on both wild-type and recombinant L-glutamate oxidase (GluOx) as the sensing element.

The enzyme reactions of GluOx to produce electroactive hydrogen peroxide (HP) can be written as Equations (1)-(2).

$$
\begin{gathered}
\text { L-Glutamate }+\mathrm{H}_{2} \mathrm{O}+\text { GluOx/FAD } \rightarrow \alpha \text {-ketoglutarate }+\mathrm{NH}_{3}+\mathrm{GluOx} / \mathrm{FADH}_{2} \\
\text { GluOx/FADH } \mathrm{FH}_{2}+\mathrm{O}_{2} \rightarrow \text { GluOx/FAD }+\mathrm{H}_{2} \mathrm{O}_{2} \\
\mathrm{H}_{2} \mathrm{O}_{2} \rightarrow \mathrm{O}_{2}+2 \mathrm{H}^{+}+2 \mathrm{e}^{-}
\end{gathered}
$$

Oxidizing this enzyme-generated HP (Equation (3)) requires a relatively high applied potential (0.4-0.7 V vs. SCE [27-29]) to provide good HP sensitivity. At these potentials, however, endogenous reducing agents, such as ascorbic acid (AA), which is present in high concentrations in most biological tissues and fluids, can give rise to false positive biosensor responses in vivo. A permselective barrier is therefore essential in the design of implantable biosensors, and a range of electro-deposited poly-phenylenediamines [30-35] and polyphenols [36-39] have been developed to improve biosensor selectivity for brain monitoring where ECF ascorbate levels are particularly high (up to $1 \mathrm{mM}$ ) [40,41].

Although polyphenols show exceptional AA-blocking characteristics [38], polyphenylenediamines are commonly the permselective membrane of choice for biosensor applications because of their high permeability to $\mathrm{HP}$ [31,42-45], in addition to excellent AA rejection. For analytical environments containing levels of AA greater than $0.2 \mathrm{mM}$, it has been suggested that poly(o-phenylenediamine), PoPD, is superior to poly ( $m$-phenylenediamine) in terms of biosensor permselectivity [44,46], and was, therefore, the interference-rejection polymer of choice in this work.

Here, we build on previous studies of PoPD-modified, wild-type GluOx-based biosensors designed for LIVE applications which have demonstrated, in addition to outstanding permselectivity, the following features: electrostatic stabilization [47] of GluOx with polycationic polyethyleneimine, PEI [26,48,49]; low limits of detection $(<1 \mu \mathrm{M})$ [50,51]; fast response times ( 1 s) [51]; and their negligible oxygen dependence (Equation (2)) for concentrations of Glu and $\mathrm{O}_{2}$ relevant to neurochemical monitoring [48,50]. However, their long-term stability was limited (days) [52]. A key aim here, therefore, was to fabricate biosensors which would be suitable for chronic implantation in brain ECF, using biosensor optimization parameters (enzyme loading, affinity, and analytical sensitivity [20]), as well as stability parameters, as guidelines. 
Initial work involved comparing a more readily available recombinant GluOx [53] with the wild-type enzyme [54] used previously in a basic PoPD/PEI/GluOx biosensor design. Then, having fine tuned the PEI/GluOx ratio, the additional strategy for engendering good stability, coupled with high values of enzyme loading, substrate affinity and sensitivity, was to include a crosslinking agent capable, inter alia, of reacting with functional groups of the three main components in the polymer-enzyme composite (PEC) layer. These crosslinkers included glutaraldehyde (GA), polyethylene glycol (PEG), and polyethylene glycol diglycidyl ether (PEGDE) introduced under different conditions. PEGDE has been used in the past [55] and more recently as a more favourable crosslinker compared with GA $[56,57]$ for the immobilization of GluOx to produce higher and more stable sensitivities. It was hoped that PEGDE would be a more suitable modifier here as it is a less disruptive crosslinker than GA, retaining greater GluOx catalytic activity [57]. Recent advances in the area of Glu biosensor development include the use of cryopreservation to retain high sensitivity to Glu for 30 days [56]. Shelf-life has also been examined, with some biosensor designs being able to retain their sensitivity to Glu after implantation [58] and for up to four months of storage [59].

By incorporating PoPD, PEI and a crosslinking agent into the biosensor design it was hoped that it would be suitable for future LIVE monitoring of Glu. Moreover, the biosensor fabrication protocols used here (electro-deposition and dip coating) lend themselves to further miniaturization, say to a micro-electrode-array (MEA) format (40-50 $\mu \mathrm{m}$ diameter) that does not induce as much tissue damage as larger probes [60], or other complications associated with damage to brain tissues [61-63].

\section{Materials and Methods}

\subsection{Reagents and Solutions}

A $200 \mathrm{U} \cdot \mathrm{mL}^{-1}$ solution of native, and a $400 \mathrm{U} \cdot \mathrm{mL}^{-1}$ solution of recombinant, glutamate oxidase (GluOx, Streptomyces sp. X-119-6; EC 1.4.3.11) in phosphate buffered saline (PBS) solution were supplied by Enzyme-Sensor Co. Ltd. (Tsukuba, Japan), and stored at $-21{ }^{\circ} \mathrm{C}$ when not in use. The $400 \mathrm{U} \cdot \mathrm{mL}^{-1}$ solution of recombinant enzyme (expressed in Escherichia coli and proteolyzed with an metalloendopeptidase from Streptomyces griseus [53]) was used here throughout, unless otherwise stated. Glutamate (Glu), o-phenylenediamine (oPD), polyethyleneimine (PEI, 50\% $w / v$ aqueous solution, $\sim 750 \mathrm{kDa}), \mathrm{HCl}(1 \mathrm{M}), \mathrm{H}_{2} \mathrm{O}_{2}(3 \%, w / w)$, PBS tablets, glutaraldehyde (GA, $\left.25 \% w / v\right)$, polyethylene glycol (PEG) and polyethylene glycol diglycidyl ether (PEGDE) were all obtained from Sigma, and used as supplied. PBS stock solutions ( $\mathrm{pH}$ 7.4) were prepared in Milli- $\mathrm{Q}^{\circledR}$ water $(18.2 \mathrm{M} \Omega \cdot \mathrm{cm})$, and stored at $4{ }^{\circ} \mathrm{C}$ as were the stock analyte solutions. A $1 \%$ PEI solution was prepared by diluting the received PEI solution in $\mathrm{H}_{2} \mathrm{O}$. A $300 \mathrm{mM}$ monomer solution of oPD was prepared in $10 \mathrm{mM} \mathrm{HCl}$. A $0.3 \% w / v$ solution of $\mathrm{H}_{2} \mathrm{O}_{2}$ was prepared in deionized water and stored in the fridge. A $1 \% w / v$ GA solution was prepared in Milli- $Q^{\circledR}$ water and stored in an active fume hood.

\subsection{Instrumentation and Software}

Chart $^{\mathrm{TM}}$ (ver. 5.2; AD Instruments Ltd., Oxford, UK) software for Windows was used for constant potential amperometry at an applied potential of either $+500 \mathrm{mV}$ (for calibrations) or $+700 \mathrm{mV}$ (for electropolymerizations) vs. a Ag pseudo-reference electrode (see Section 2.3). The Chart software was required to operate the Powerlab 8/30 (AD Instruments Ltd.) interfaced to the ACM-IV potentiostat (Biostat IV, ACM Instruments, Cumbria, UK). Prism (ver. 5.01; GraphPad Software, San Diego, CA, USA) was used for data analysis.

\subsection{Amperometric Experiments}

All experiments were done in a $20 \mathrm{~mL}$ glass cell containing PBS (pH 7.4) at an ambient $21 \pm 1^{\circ} \mathrm{C}$, using a standard three-electrode set-up, including a silver pseudo-reference electrode ( $250 \mu \mathrm{m}$ diameter Ag wire) whose potential in PBS was within $30 \mathrm{mV}$ of a SCE (similar to that reported for Ag pseudo-references in other background electrolyte solutions with like chloride-ion concentration [27]), 
and a stainless-steel needle as the auxiliary electrode $(0.8 \mathrm{~mm}$ diameter). The working electrodes were platinum-iridium wires (90:10 ratio, Advent Research Materials Ltd., Oxford, UK) stress-relieved Teflon ${ }^{\circledR}$-insulated wire, 125 - $\mu \mathrm{m}$ internal diameter. Glu and HP calibrations were performed in quiescent PBS (following stabilization of the background current for $1 \mathrm{~h}$ ) by adding aliquots of Glu or HP stock solution to a stirred solution of PBS in the electrochemical cell, and allowing the solution to become quiescent. For electropolymerization in the $300 \mathrm{mM}$ oPD solution, an optimized potential of $+0.7 \mathrm{~V}$ vs. the Ag pseudo-reference electrode was applied for $15 \mathrm{~min}$ [64].

\subsection{Electrode Preparation and Modification}

\subsubsection{Electrode Preparation}

Approximately $2 \mathrm{~mm}$ of Teflon ${ }^{\circledR}$ was removed from the Pt-Ir wire electrode using a scalpel in a rolling movement. This was cut more accurately using a monocle under a light microscope to $1.0 \pm 0.1 \mathrm{~mm}$. Approximately $2 \mathrm{~mm}$ of Teflon was removed from the other end of the wire and this was soldered to a gold clip to facilitate the connection of the working electrode to the potentiostat circuit. Compared with pure Pt, the mechanically more robust Pt-Ir working electrodes have similar electrochemical properties and are more generally used for implantable biosensors [44]; they are normally designated as $\mathrm{Pt}$, however, for simplicity of biosensor notation (see Section 2.5).

\subsubsection{Electrode Modification}

Dip evaporation was used to immobilize PEI and GluOx by quickly dipping the wire electrode into an Eppendorf tube containing the corresponding solution for $\sim 1 \mathrm{~s}$ and then allowed to dry for $5 \mathrm{~min}$ at room temperature. This process was repeated a specified number of times to increase the amount of macromolecular material deposited. In some biosensor designs the enzyme was trapped on the surface of the biosensor, using either GA, PEG or PEGDE, by dipping the biosensor once into a solution containing the crosslinker at various concentrations and then cured under different conditions. For PEG and PEGDE crosslinking, the electrodes were dipped into a solution of the crosslinker for $1 \mathrm{~s}$, and allowed to cure at room temperature for $10 \mathrm{~min}$, unless stated otherwise. The electrodes were then rinsed in water for $5 \mathrm{~min}$, immersed in a fresh solution of PBS in the electrochemical cell, a potential of $+0.5 \mathrm{~V}$ applied, and allowed to settle for $1 \mathrm{~h}$ before calibration.

\subsection{Biosensor Nomenclature}

The order of deposition of the various biosensor components is important in optimizing biosensor functionality (sensitivity, selectivity and stability), and the nomenclature used to represent each design should reflect this order. In the system used here [20], $\mathrm{Pt}_{\mathrm{C}}$ represents the Pt-Ir wire with a cylinder geometry, and the modifier deposition sequence is the same as in the nomenclature. For example, $\mathrm{Pt}_{\mathrm{C}} / \mathrm{PoPD} / \mathrm{GluOx}$ indicates that the PoPD polymer was electropolymerized directly onto the metal surface, followed by deposition of the GluOx enzyme. Dip evaporation is a technique commonly used to apply modifier to electrode surfaces [56,65], and varying the number of dips can be used facilely to build up the amount of modifier deposited. There was a need, therefore, to represent this with a number after the modifier. For example, $\mathrm{Pt}_{\mathrm{C}} / \mathrm{PoPD} / \mathrm{PEI}_{2} / \mathrm{GluOx}_{5} / \mathrm{PEGDE}(0.1 \%)$ represents a PoPD polymer-coated Pt electrode modified by two dips of PEI solution (a fixed concentration of $1 \%$ PEI was used throughout this study) followed by five dips of GluOx (fixed concentration of $400 \mathrm{U} \cdot \mathrm{mL}^{-1}$ (as supplied) throughout this study), followed by crosslinking with 1 dip of $0.1 \%$ PEGDE.

\subsection{Data Analysis}

\subsubsection{Hydrogen Peroxide Sensitivity Ratio, HP\%}

Because HP is the enzyme signal-transduction molecule for the oxidase-based biosensors studied here (Equations (2) and (3)), we quantified the effect of various biosensor modifications on its 
$\mathrm{HP}$ sensitivity by measuring the $\mathrm{HP}$ response of the Pt before and after modification, $\mathrm{HP}(\mathrm{bare})$ and $\mathrm{HP}$ (bios), respectively, for each individual sensor. The HP calibration slope was linear in the concentration range studied $(0-100 \mu \mathrm{M})$ for both bare $\mathrm{Pt}_{\mathrm{C}}$ and PoPD-based polymer-enzyme composite biosensors, as observed previously [31,44]. The HP sensitivity was therefore quantified as the slope of the linear HP calibration plots, and their ratio ( $\mathrm{HP} \%$ ) used to quantify the effect of the modification layers on the HP sensitivity; see Equation (4).

$$
\mathrm{HP} \%=\frac{\mathrm{HP}(\text { bios }) \times 100}{\mathrm{HP}(\text { bare })}
$$

\subsubsection{Michaelis-Menten Parameters}

Oxidase-based biosensor responses are often essentially hyperbolic, and can be modeled using a Michaelis-Menten kinetic analysis (see Figure 1) [44]. Equation (5) is the enzyme-kinetic equation expressed in terms of current density $\left(J_{S}\right)$ of the background-corrected biosensor response to substrate (S) at a concentration [S]. JMAX is the current that would be observed at enzyme saturation and $K_{\mathrm{M}}$ is the apparent Michaelis constant, an affinity parameter that defines the concentration of substrate, which gives half the $J_{\text {MAX }}$ response (Figure 1). For each biosensor design, the current density values of the calibration were plotted against the Glu concentration and non-linear regression used to determine the $J_{\mathrm{MAX}}$ and $K_{\mathrm{M}}$, using Equation (5). Although the biosensor response was hyperbolic over a wide range of concentrations (average Hill coefficient was $1.3 \pm 0.3(\mathrm{SD}), n=30$, and not very different from unity), it is approximately linear up to $\sim \frac{1}{2} K_{\mathrm{M}}$, with a corresponding linear region slope (LRS) value which is often used to quantify biosensor sensitivity to substrate. The limit of the LRS as [S] $\rightarrow 0$ is the maximum slope, with a value of $J_{M A X} / K_{M}$ [20]; see Figure 1 . The average coefficient of determination ( $R^{2}$ value) for the LRS from a large sample population was $0.990 \pm 0.002$, $n=100$. Therefore, both Michaelis-Menten non-linear and linear regression analyses were used for Glu calibrations. Linear regression analysis only was needed for HP calibrations.

$$
J_{S}=\frac{J_{\mathrm{MAX}}}{1+K_{\mathrm{M}} /[S]}
$$

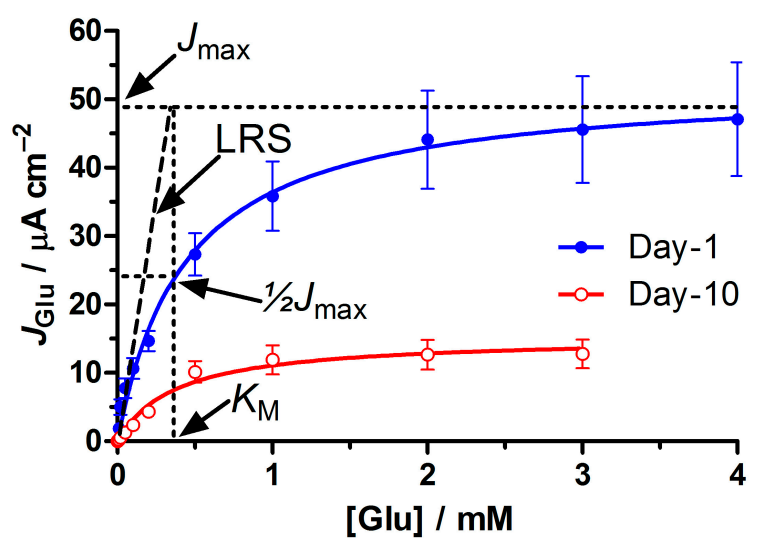

Figure 1. Initial studies using recombinant GluOx in combination with PEI, but without a permselective barrier or crosslinking agent. Calibration data and non-linear regression (Equation (5); $R^{2}=0.985 \pm 0.003$ ) for the $\mathrm{Pt}_{\mathrm{C}} / \mathrm{PEI}_{2} / \mathrm{GluOx}_{5}$ design illustrating the Michaelis-Menten kinetic parameters, $J_{\max }$ and $K_{\mathrm{M}}$, shortly after fabrication, as well as loss of active surface enzyme by day 10 .

\subsubsection{Normalized Enzyme Parameters, BE\% and Enzact}

Because the biosensor response to substrate Glu depends on its HP sensitivity (Equations (1)-(3)), a number of key parameters such as $J_{\text {MAX }}$ and LRS (see Figure 1) were normalized with respect 
to biosensor HP sensitivity. The biosensor efficiency or BE\% (Equation (6)) can be thought of as a measure of the efficiency of the biosensor in converting substrate (S) to HP [20]. This parameter was used because there may be some variation in the Glu LRS caused by changes in the sensitivity of the biosensor to HP, such as electrode aging; the LRS was therefore normalized with respect to the biosensor HP slope, and since the LRS has a limiting value of $J_{\mathrm{MAX}} / K_{\mathrm{M}}[20], \mathrm{BE} \%$ reflects the major enzyme parameters determining biosensor response to substrate (loading of active enzyme and enzyme affinity), but is independent of HP sensitivity (Equation (6)). The maximum observed value of $\mathrm{BE} \%$ to date is of the order of $60 \%$ [44,47], which corresponds to Glu being converted to HP at a diffusion-limited rate, coupled with a significant fraction of enzyme-generated HP molecules not being oxidized at the electrode because of loss to the bulk solution [66].

$$
\mathrm{BE} \%=\frac{\mathrm{LRS} \times 100}{\mathrm{HP}(\text { bios })}=\frac{J_{\mathrm{MAX}} \times 100}{K_{\mathrm{M}} \times \mathrm{HP}(\text { bios })}=\frac{\text { Enz }_{\mathrm{act}} \times 100}{K_{\mathrm{M}}}
$$

Enzact (Equation (7)) has been used in the past to give an indication of active enzyme loading on

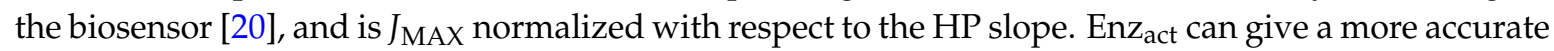
indication of active enzyme loading than $J_{\text {MAX }}$ because variations in $J_{\text {MAX }}$ may occur which are due to changes in biosensor HP sensitivity, enzyme loading or enzyme activity. Thus, by normalizing $J_{\text {MAX }}$ with respect to HP sensitivity it is possible to compare the loading of active enzyme molecules that contribute to the biosensor response across different biosensor designs. For example, enzyme molecules that are located far from the Pt electrode surface (say, stacked on multiple layers of PEI) might not contribute significantly to the biosensor response because most of the enzyme-generated HP may diffuse to the bulk solution before it can be electro-oxidized. The units of Enzact are given in $\mathrm{mM}$, and represent the concentration of hydrogen peroxide that gives the same biosensor response as the Glu $J_{\max }$ value.

$$
\mathrm{Enz}_{\mathrm{act}}=\frac{J_{\mathrm{MAX}}}{\mathrm{HP}(\text { bios })}
$$

\subsection{Statistical Analysis}

All data are reported as mean \pm standard error (SEM), with $n$ the number of electrodes, unless stated otherwise. Student's $t$-tests were used to compare different biosensor configurations, as well as time-dependent changes for a given design, and the difference deemed to be statistically significant for $p<0.05$, using a 95\% confidence interval. A common estimate of limit of detection (LOD) [34] was calculated for these biosensors, using Equation (8), where SD is the standard deviation of the baseline biosensor current in background electrolyte.

$$
\mathrm{LOD}=3.3 \mathrm{SD} / \mathrm{LRS}
$$

\section{Results and Discussion}

\subsection{Optimizing the Ratio of PEI to GluOx}

PEI, a polycationic polymer, is commonly used for the immobilization and stabilization of enzymes on biosensor surfaces [47,67-69], and was used here in all biosensor designs to help neutralize the electrostatic charge associated with high loading of anionic GluOx on the electrode surface. This is particularly important when the enzyme substrate is anionic, as in the case of Glu detection at $\mathrm{pH}$ values close to neutrality [47]. In the absence of PEI, a high surface loading of wild-type GluOx has been shown to result in a high $K_{M}$ value, i.e., a low affinity of Glu for the enzyme, which was reversed by surface PEI $[26,48]$. The balance of PEI and recombinant GluOx loading was therefore investigated here to provide the best analytical parameters (especially sensitivity and stability) for long-term Glu monitoring. Varying amounts of PEI and GluOx (PEI/GluOx $2, \mathrm{PEI} / \mathrm{GluOx}_{5}, \mathrm{PEI}_{2} / \mathrm{GluOx}_{2}$, $\mathrm{PEI}_{2} / \mathrm{GluOx}_{5}, \mathrm{PEI}_{5} / \mathrm{GluOx}_{5}$, and $\mathrm{PEI}_{4} / \mathrm{GluOx}_{10}$; see Section 2.5 for biosensor nomenclature) were dip 
evaporated onto the bare $\mathrm{Pt}$ wire cylinder electrodes, and calibrations performed to compare levels of enzyme loading, substrate affinity, and biosensor efficiency (see Equations (5)-(7)). These initial studies focused on relatively freshly-made biosensors (calibrated daily up to day 10). Quantification of long-term biosensor stability (up to 90 days) was carried out later on the fine-tuned designs.

Glutamate calibrations of all $\mathrm{Pt}_{\mathrm{C}} / \mathrm{PEI}_{\mathrm{m}} / \mathrm{GluOx}_{\mathrm{n}}$ designs followed Michaelis-Menten kinetics (see Figure 1). For these initial studies using recombinant GluOx in combination with PEI, but without a permselective barrier or crosslinking agent, the Glu sensitivity tended to decrease on the days following biosensor fabrication (see Figure 1). This sensitivity can be expressed either in terms of the biosensor response when the enzyme is saturated $\left(J_{\max }\right)$ or the slope of the linear region (LRS $=J_{\max } / K_{\mathrm{M}}[50]$; see Figure 1). The former is a useful index of the loading of active enzyme on the surface, but is also affected by biosensor hydrogen peroxide (HP) sensitivity (Equations (1)-(3)). Here, therefore, each $J_{\max }$ value was normalized with respect to the HP sensitivity determined by HP calibration of the corresponding biosensor. Using Equation (7), this provides Enzact, a parameter which more closely reflects variations in the loading of active enzyme across a range of biosensor configurations, or during the aging of a specific design (see Section 2.6.3 for definitions and the significance of the units).

\subsubsection{GluOx Loading Parameter, Enzact}

The importance of surface PEI in biosensors designed for long-term monitoring of Glu was demonstrated by the behavior of the PEI-free configuration $\left(\mathrm{Pt}_{\mathrm{C}} / \mathrm{GluOx}_{5}\right)$, which displayed a low normalized $J_{\max }$ value $\left(\right.$ Enz $\left._{\mathrm{act}}, 2.0 \pm 0.3 \mathrm{mM}, n=4\right)$ even for calibrations carried out on the day of fabrication (day 0; see Figure 2a). Furthermore, this meagre loading level was lost completely by day 2 : $0.01 \pm 0.01 \mathrm{mM}, n=4$.

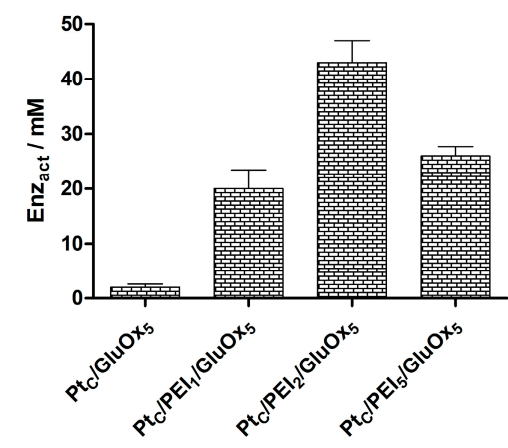

(a)

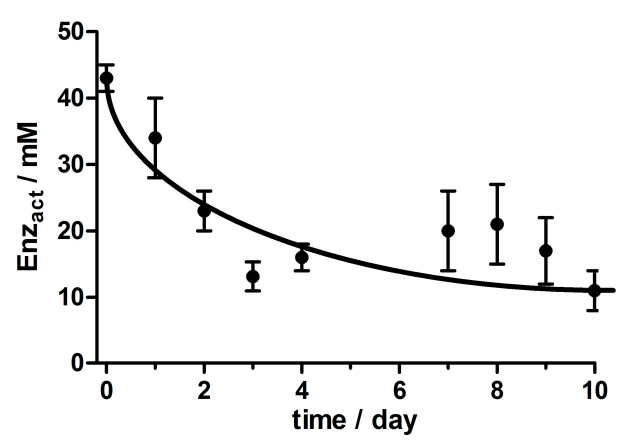

(b)

Figure 2. Initial studies using recombinant GluOx in combination with PEI, but without a permselective barrier or crosslinking agent: (a) Comparison of day-0 HP-normalized $J_{\max }$ value (Enz $\mathrm{act}_{\text {; }}$ see Equation (7)) for $\mathrm{Pt}_{\mathrm{C}} / \mathrm{PEI}_{\mathrm{X}} / \mathrm{GluOx}_{5}$ designs, with $\mathrm{x}=0,1,2$ and 5 (see text for discussion); (b) Time course of data and trend-curve up to day 10 for the $\mathrm{Pt}_{\mathrm{C}} / \mathrm{PEI}_{2} / \mathrm{GluOx}_{5}$ design showing loss of active enzyme loading, using the Enzact values.

The ratio of $\mathrm{PEI}$ to GluOx which gave the highest initial (day 0) Enzact value was $\mathrm{Pt}_{\mathrm{C}} / \mathrm{PEI}_{2} / \mathrm{GluOx}_{5}$ (43 $\pm 2 \mathrm{mM}, n=4$; see Figure 2), resulting from a combination of high $J_{\max }$ and good biosensor sensitivity to hydrogen peroxide. A 40\% lower Enzact value was observed for the second-best biosensor configuration $\left(\mathrm{Pt}_{\mathrm{C}} / \mathrm{PEI}_{5} / \mathrm{GluOx}_{5}, 26 \pm 1 \mathrm{mM}, n=3 ; p<0.005\right.$ compared with the $\mathrm{Pt}_{\mathrm{C}} / \mathrm{PEI}_{2} / \mathrm{GluOx}_{5}$ design). The lowest $\mathrm{Enz}_{\mathrm{act}}$ value was seen for the $\mathrm{Pt}_{\mathrm{C}} / \mathrm{PEI} / \mathrm{GluOx_{2 }}$ design $(19 \pm 2 \mathrm{mM}, n=3)$, which was significantly lower than for the $\mathrm{Pt}_{\mathrm{C}} / \mathrm{PEI}_{2} / \mathrm{GluOx}_{5}$ design $(p<0.001)$. These day-0 results highlight the importance of the balance of surface PEI and GluOx, rather than simply the amount of each compound deposited, in order to achieve good initial enzyme loading.

Finally in this context, a doubling of the number of dips for the best PEI:GluOx ratio (2:5), corresponding to a $\mathrm{Pt}_{\mathrm{C}} / \mathrm{PEI}_{4} / \mathrm{GluOx}_{10}$ design, gave a poorer Enzact value on day $0(26 \pm 2 \mathrm{mM}$, 
$n=9)$ compared with the $\mathrm{Pt}_{\mathrm{C}} / \mathrm{PEI}_{2} / \mathrm{GluOx}_{5}$ configuration $(p<0.001)$, and more closely resembled the active enzyme loading of $\mathrm{Pt}_{\mathrm{C}} / \mathrm{PEI}_{5} / \mathrm{GluOx}_{5}(p>0.95)$. These results are consistent with the interpretation of Enzact given in Section 2.6.2: excessive layers of macromolecular PEI ( 750 kDa) increase the average distance between GluOx and the Pt surface, leading to increased diffusional loss of enzyme-generated HP to the bulk, and a corresponding lowering of biosensor response. The finding that the $\mathrm{Pt}_{\mathrm{C}} / \mathrm{PEI}_{2} / \mathrm{GluOx}_{5}$ design was superior to the other configurations of PEI and recombinant GluOx explored here is consistent with the same conclusion drawn from a comparison of biosensors based on wild-type GluOx [47]; see also Section 3.3.

There was no clear trend in the effect on HP sensitivity (linear calibration slope, $\mu \mathrm{A} \cdot \mathrm{cm}^{-2} \cdot \mathrm{mM}^{-1}$ ) for different loading levels of PEI and GluOx on the Pt surface, and the data were therefore pooled $(n=16)$ : bare $\mathrm{Pt}_{\mathrm{C}}(179 \pm 20)$ and $\mathrm{Pt}_{\mathrm{C}} / \mathrm{PEI}_{\mathrm{m}} / \mathrm{GluOx}_{\mathrm{n}}(138 \pm 23)$. Equation (4) gave a $\mathrm{HP} \%$ value of $77 \% \pm 15 \%$ ( $p=0.06$ compared with the ideal value of 100\%), indicating that the deposition of these macromolecules caused only a marginal decrease in biosensor HP sensitivity relative to bare Pt.

There was also little variation in the $K_{\mathrm{M}}$ values across all the basic $\mathrm{Pt}_{\mathrm{C}} / \mathrm{PEI}_{n} / \mathrm{GluOx}_{\mathrm{m}}$ designs and, in contrast to the progressive loss of active enzyme molecules over the first 10 days of repeated calibration (see Figures 1 and $2 b$ ), there was no statistically significant change in $K_{M}$ over this period. The values were, therefore, pooled and expressed as a mean \pm SD: $0.4 \pm 0.1 \mathrm{mM}(n=104$ determinations). This value for the surface-bound enzyme is expectedly greater than that reported for solution GluOx (0.23 mM for both the wild type [54] and recombinant type [53] used here; see explicit comparison in Section 3.3) because of restriction of Glu access to the biosensor GluOx by the surface itself, reducing the binding rate constant. In contrast, the increase in $K_{\mathrm{M}}$ caused by enzyme-substrate electrostatic repulsion in PEI-free Glu biosensor designs in a previous study was of the order of $1.5 \mathrm{mM}$ for the upper loading levels seen here for biosensors incorporating PEI [50]. The maintenance of the mean $K_{\mathrm{M}}$ value below $0.5 \mathrm{mM}$ for the $\mathrm{Pt}_{\mathrm{C}} / \mathrm{PEI}_{\mathrm{n}} / \mathrm{GluOx}_{\mathrm{m}}$ designs indicates that the PEI was efficiently moderating the electrostatic repulsion between anionic surface enzyme and substrate [47].

\subsubsection{Biosensor Efficiency Parameter, BE\%}

This parameter (Equation (6)) incorporates influences from enzyme loading and substrate affinity. It is the most important of the different parameters studied here because it indicates how efficiently the biosensor enzyme composite layer converts Glu to electrochemical current (Equations (1)-(3)), and is the Glu linear region slope (Figure 1) normalized with respect to hydrogen peroxide sensitivity for each individual biosensor. This normalization is a key feature in biosensor optimization for LIVE applications because hydrogen peroxide is generated in living tissues from a variety of metabolic processes [70], and therefore may act as a biosensor interference species under some conditions. Enhancing the biosensor signal, therefore, using a strategy which also increases the hydrogen peroxide current, such as roughening the electrode surface [71], would not be as effective as augmenting the efficiency of the enzyme layer in converting Glu to hydrogen peroxide, which was the main goal of the present work.

In line with previous results for wild-type GluOx [47], and enzyme loading and affinity results above for recombinant GluOx, the biosensor design, which gave the highest value of biosensor efficiency (BE\%), was $\mathrm{Pt}_{C} / \mathrm{PEI}_{2} / \mathrm{GluOx}_{5}(45 \% \pm 3 \%, n=4)$, which halved to $22 \% \pm 4 \%(n=4)$ by day 10, and reflecting mainly loss of active enzyme from the biosensor surface (see Figure $2 \mathrm{~b}$ ). This contrasts with the least stable PEI-containing design $\left(\mathrm{Pt}_{\mathrm{C}} / \mathrm{PEI}_{5} / \mathrm{GluOx}_{5}\right)$ where the maximum $\mathrm{BE} \%$ was $35 \% \pm 1 \%(n=3)$, which halved by day 3 . On the basis of these results, it was decided to take the $\mathrm{PEI}_{2} / \mathrm{GluO}_{5}$ design forward, unless otherwise stated, for further optimization to increase enzyme loading, efficiency, and biosensor stability.

\subsection{Biosensor Performance in the Presence and Absence of the Permselective PoPD Layer}

Because an interference-blocking layer is necessary in biosensors for LIVE applications, the effects of electrosynthesized PoPD (a well-established permselective polymer for neurochemical monitoring 
in vivo [44,72-76]) on the biosensor enzyme performance was investigated. The electropolymerization of PoPD, and its subsequent conditioning, is time consuming ( $3 \mathrm{~h}$ ). Thus, it was hoped that the more facile PoPD-free biosensor designs could be optimized, and then PoPD introduced into the final design. In addition, the exclusion of PoPD in the design could be further justified as the interference-rejection properties of the Glu biosensor was not the main focus here, which was the effects of a range of crosslinkers on the Glu biosensor sensitivity and stability. The performance of various $\mathrm{Pt}_{\mathrm{C}} / \mathrm{PEI}_{n} / \mathrm{GluOx}_{\mathrm{m}}$ designs was therefore tested in the presence and absence of PoPD to investigate whether the polymer was having a significant impact on the key enzyme-related biosensor parameter, $\mathrm{BE} \%$.

An unpaired $t$-test analysis showed that PoPD had only marginal beneficial effects on both Enz $_{\text {act }}(\sim 20 \%$ increase $)$ and $K_{\mathrm{M}}(\sim 20 \%$ decrease). However, $\mathrm{BE} \%$, which is a combination of these two parameters (Equation (6)), displayed a significant enhancement $(64 \% \pm 6 \%, n=27 ; p<0.001)$ when PoPD was incorporated into a variety of PEI/GluOx biosensor designs, indicating that the inclusion of PoPD is beneficial by improving the overall efficiency of the biosensor enzyme layer. Therefore, PoPD was included in the previously chosen design (giving $\mathrm{Pt}_{C} / \mathrm{PoPD} / \mathrm{PEI}_{2} / \mathrm{GluOx}_{5}$ ) for all further stages of biosensor optimization.

\subsection{Within-Study Comparison of Native and Recombinant GluOx Forms}

Many previously reported descriptions of PEI-containing Glu biosensors were based on wild-type GluOx $[26,49,77,78]$. Since recombinant enzyme is now more readily available [53], a comparison of biosensor parameters for native vs. recombinant $\mathrm{GluOx}$ was undertaken. To include the key property of stability, the range of analytical parameters were therefore reviewed following 11 days of successive calibrations for the partially optimized $\mathrm{Pt}_{\mathrm{C}} / \mathrm{PoPD} / \mathrm{PEI}_{2} / \mathrm{GluOx}_{5}$ design, containing either native or recombinant GluOx.

On day 11, the Enzact value for the biosensor featuring recombinant GluOx $(18 \pm 3 \mathrm{mM}, n=4)$ was not statistically different from that containing the native form of GluOx (13 $\pm 5 \mathrm{mM}, n=3, p>0.80)$. The $K_{\mathrm{M}}$ values on day 11 for the recombinant and native GluOx biosensor designs were also not statistically different from each other: $0.50 \pm 0.05 \mathrm{mM}(n=4)$ and $0.44 \pm 0.02 \mathrm{mM}(n=3)$, respectively $(p>0.26)$. Given the similarity of the loading and affinity characteristics of biosensors fabricated from these two GluOx forms, it was not surprising that the $\mathrm{BE} \%$ values on day 11 for the recombinant and native GluOx biosensor designs were statistically the same: $26 \% \pm 2 \%(n=4)$ and $23 \% \pm 8 \%(n=3)$, respectively $(p>0.74)$.

It is clear, therefore, that the quality of the biosensor was not compromised by the use of recombinant GluOx. Because recombinant forms of GluOx are now widely available, and used by many laboratories $[55,79,80]$, it was utilized in the further development of Glu biosensors described below. Specifically, a variety of crosslinking agents were tested in attempts to increase initial active enzyme loading, as well as mitigate its subsequent loss from the biosensor surface (see Figures 1 and 2).

\subsection{Glutaraldehyde}

Glutaraldehyde (GA) is a 5-carbon dicarbonyl, which has been employed successfully in biosensor enzyme crosslinking in the past [81-83], and was used here in initial attempts to retain GluOx on the biosensor surface. Unfortunately, there are drawbacks associated with its use, such as the health hazards related to its handling and the unwanted partial deactivation of enzymes which may occur following the crosslinking reaction. For example, there was an increase in $K_{\mathrm{M}}$ when the chosen biosensor design $\left(\mathrm{Pt}_{\mathrm{C}} / \mathrm{PoPD} / \mathrm{PEI}_{2} / \mathrm{GluOx}_{5}\right)$ was exposed to $1 \% \mathrm{GA}$ for $5 \mathrm{~s}$ and left to dry for $10 \mathrm{~min}$ : from $0.4 \pm 0.1 \mathrm{mM}$ to $1.3 \pm 0.2 \mathrm{mM}(p<0.003, n=6)$.

In deference to the longstanding use of GA in biosensor design [82], an attempt was made to exploit this agent and minimize the amount of GluOx damage by controlling the GA reaction. In contrast to previous studies where very low concentrations of GA have been used, together with incorporation of a non-enzyme protein (usually bovine serum albumin) into the crosslinking medium 
to limit enzyme deactivation [84,85], GluOx protection was attempted here by adjusting the exposure time of the biosensor to GA and by controlling the subsequent crosslinking reaction by quenching in water for predetermined times. Therefore, GA was introduced to the $\mathrm{Pt}_{\mathrm{C}} / \mathrm{PoPD} / \mathrm{PEI}_{2} / \mathrm{GluOx}_{5}$ design to establish which combination of exposure and quenching times would result in the most favorable outcome.

Initially, biosensors were exposed to a concentration of $25 \%$ GA for either 5 or $10 \mathrm{~s}$, followed by quenching times of $10 \mathrm{~min}$ or $1 \mathrm{~h}$. The initial focus was the $K_{\mathrm{M}}$ values as they represent the change in substrate affinity for the GluOx. The $K_{\mathrm{M}}$ for biosensors exposed to GA for $5 \mathrm{~s}$ and quenched for $1 \mathrm{~h}$ was $0.50 \pm 0.06 \mathrm{mM}(n=8)$, whereas a quenching time of $10 \mathrm{~min}$ led to the indistinguishably similar $K_{\mathrm{M}}$ value: $0.58 \pm 0.16 \mathrm{mM}(n=8, p>0.6)$. These results indicate that $10 \mathrm{~min}$ was sufficient for the quenching of the crosslinking reaction to a level that protected the GluOx, and this quenching time was used for subsequent GA experiments. A longer exposure time of $10 \mathrm{~s}$, followed by quenching, resulted in a $K_{\mathrm{M}}$ of $0.69 \pm 0.06 \mathrm{mM}(n=8, p<0.05)$, indicating a marginally significant loss of enzyme affinity for its substrate and an upper limit to exposure time.

A lower GA concentration (1\% GA) was also examined and compared with both $25 \%$ GA and GA-free biosensor designs. The effects of varying the GA concentrations ( $0 \%, 1 \%$ and $25 \%)$ on the enzyme-related biosensor parameters are described in more detail in the following section.

Effect of Glutaraldehyde on BE\%

As illustrated in Section 3.2, the biosensor efficiency parameter BE\% (Equation (6)) is quite a sensitive index of the effects of biosensor modification on the response of the enzyme composite layer to substrate, and was therefore analyzed in detail here to probe the influence of GA (see Table 1).

Table 1. BE\% (Equation (6)) for the biosensor designs $\mathrm{Pt}_{\mathrm{C}} / \mathrm{PoPD} / \mathrm{PEI}_{2} / \mathrm{GluOx}_{5} / \mathrm{XL}$ fabricated using a range of crosslinkers (XLs) at different concentrations and crosslinking conditions determined on day 0 and day $10 . \triangle \mathrm{BE} \%$ (day 0 ) is the difference in the day- $0 \mathrm{BE} \%$ value compared with the crosslinker-free design. The 10-day stability value was calculated as the change in $\mathrm{BE} \%$ on day 10 compared with that of day 0 for each biosensor design. The results for PEGDE crosslinked at room temperature or at $55^{\circ} \mathrm{C}$ were statistically the same, and were, therefore, pooled.

\begin{tabular}{ccccccc}
\hline Crosslinker & BE\% (Day 0) & BE\% (Day 10) & $\mathbf{\Delta B E \% ~ ( D a y ~ 0 ) ~}$ & $\boldsymbol{p}$-Value & 10-Day Stability & $p$-Value \\
\hline none & $41 \pm 2(n=16)$ & $26 \pm 3(n=14)$ & 0 & N/A & $-15 \pm 4$ & $<0.001$ \\
GA (1\%) & $37 \pm 1(n=2)$ & $23 \pm 2(n=2)$ & $-4 \pm 2$ & $>0.61$ & $-14 \pm 3$ & $<0.03$ \\
GA (25\%) & $39 \pm 3(n=8)$ & $45 \pm 3(n=6)$ & $-3 \pm 4$ & $>0.57$ & $+6 \pm 4$ & $>0.19$ \\
PEG (0.1\%) & $45 \pm 2(n=3)$ & $19 \pm 6(n=3)$ & $+4 \pm 3$ & $>0.41$ & $-26 \pm 5$ & $<0.02$ \\
PEG (1\%) & $45 \pm 8(n=3)$ & $21 \pm 6(n=3)$ & $+4 \pm 7$ & $>0.46$ & $-24 \pm 9$ & $-5 \pm 4$ \\
PEGDE (0.1\%) & $39 \pm 2(n=7)$ & $34 \pm 3(n=7)$ & $-2 \pm 3$ & $>0.55$ & $+1 \pm 4$ & $>0.28$ \\
PEGDE (1\%) & $34 \pm 2(n=12)$ & $35 \pm 3(n=12)$ & $-7 \pm 3$ & $<0.05$ & & \\
\hline
\end{tabular}

The $\mathrm{BE} \%$ value of the crosslinker-free design $\left(\mathrm{Pt}_{\mathrm{C}} / \mathrm{PoPD} / \mathrm{PEI}_{2} / \mathrm{GluOx}_{5}\right.$ ) decreased from $41 \% \pm 2 \%$ $(n=16)$ on day 0 to $26 \% \pm 3 \%(n=14)$ on day 10 , representing a $36 \%$ loss of HP-normalized sensitivity over the 10 day period ( $p<0.001$; see Table 1 ). The $1 \%$ GA treatment did not affect BE\% on day 0 compared with the GA-free design $(p>0.61)$; however, neither did it affect the loss of efficiency over the 10 days (38\% loss, $p<0.03$ ). Again, the $25 \%$ GA treatment did not affect BE $\%$ on day 0 compared with the GA-free design ( $p>0.57)$, highlighting the protective effect of the quenching protocol. However, in contrast to the $1 \%$ GA treatment, exposure of the biosensor to this high concentration of GA completely prevented the decrease in $\mathrm{BE} \%$ over the 10 days (Table 1 ).

\subsection{Effect of Other Crosslinking Agents on BE\%}

The use of GA in the biosensor design was deemed to be successful because it led to a more stable biosensor when compared to the corresponding crosslinker-free design (Table 1). The large increase in $K_{\mathrm{M}}$ observed under some crosslinking conditions was alleviated by controlling the exposure time to 
GA and by quenching the reaction. However, due to the hazards associated with the use of GA, other crosslinkers were investigated, starting with polyethylene glycol, PEG.

\subsubsection{Polyethylene Glycol, PEG}

PEG, which is capable of crosslinking to GluOx through its reaction with carboxyl groups present on GluOx, was an attractive modifier here as it is nontoxic and has been shown not to affect the biological activities of enzymes [86]. Both the absolute values and the time course for changes in $\mathrm{BE} \%$ were statistically the same when either $0.1 \%$ or $1 \%$ PEG was used as the crosslinker (Table 1 ). As observed for biosensors incorporating GA, day $0 \mathrm{BE} \%$ values were indistinguishable from the crosslinker-free design. However, the PEG-based designs showed no ability to protect the biosensor enzyme layer from loss of sensitivity over the initial 10-day period.

\subsubsection{Poly(ethyleneglycol) Diglycidyl Ether, PEGDE}

Activated PEG in the form of PEGDE is a highly soluble polymer and is capable of crosslinking with enzymes through covalent and non-covalent interactions. PEGDE is reactive towards the various functional groups on proteins (amines, carboxyl and hydroxyl groups) owing to the highly reactive epoxy terminal groups present on PEGDE. This crosslinking agent has been used successfully in the past with glucose oxidase [87], and more recently by Vasylieva and co-workers with a variety of oxidase enzymes [88]. PEGDE was used here in two ways: at room temperature; and at elevated temperatures whereby the sensors were cured for $2 \mathrm{~h}$ at $55^{\circ} \mathrm{C}$ to allow for the possibility of a more effective crosslinking reaction [88].

There was no statistically significant difference between either the two PEGDE concentrations $(0.1 \%$ or $1 \%)$ or crosslinking temperature on day 0 when compared with the crosslinker-free design (see Table 1). In contrast to PEG designs, all PEGDE configurations were able to prevent any loss of Glu sensitivity over the first 10 days of operation, with 1\% PEGDE being marginally more effective than the $0.1 \%$ crosslinking solution. The data in Table 1 show clearly that PEGDE was as effective in stabilizing the biosensors as quenched GA crosslinking, without the corresponding handling hazards.

\subsection{Limit of Detection, and Response Time}

There was no significant difference between the LOD values ( $\mu \mathrm{M} \mathrm{Glu}$ ) determined for sample sets of each key design with the generic form $\mathrm{Pt}_{\mathrm{C}} / \mathrm{PoPD} / \mathrm{PEI}_{2} / \mathrm{GluOx}_{5} / \mathrm{XL}$, where $\mathrm{XL}$ is the crosslinking agent: no crosslinking agent $(0.42 \pm 0.08, n=13)$; GA $(0.22 \pm 0.04, n=4)$; PEG $(0.16 \pm 0.03, n=6)$; PEGDE $(0.17 \pm 0.05, n=6)$. These values indicate that the sensitivity is adequate for LIVE applications in brain ECF, where baseline Glu levels have been estimated to be in the low micromolar range (see Section 1). This is a necessary, but not sufficient, criterion for successful LIVE monitoring, where fast response time and long-term stability are also critical requirements.

The time response $\left(t_{90} \%\right.$ of the crosslinker-free design $\left(\mathrm{Pt}_{\mathrm{C}} / \mathrm{PoPD} / \mathrm{PEI}_{2} / \mathrm{GluOx}_{5}\right)$ was fast: $0.9 \pm 0.2 \mathrm{~s}, n=6$, which is consistent with previous findings for other configurations of Glu biosensors based on wild-type GluOx and the ultrathin PoPD permselective polymer [50]. Crosslinking the PEI-GluOx layer with GA had a non-significant effect on $t_{90} \%$ values $(1.2 \pm 0.1 \mathrm{~s}, n=4 ; p>0.28)$. The effect of the two milder crosslinking agents (PEG and PEGDE) were similar, and were therefore pooled: $0.8 \pm 0.1 \mathrm{~s}, n=27$. This was statistically significantly better than GA $(p<0.005)$, and the same as the crosslinker-free configuration $(p>0.67)$. This sub-second response time for the chosen crosslinker PEGDE is adequate for monitoring Glu concentration dynamics in future studies of brain extracellular fluid where diffusion from the synapse [89] dampens the sub-millisecond transients observed within the synaptic cleft [90]. These response-time results also revealed an additional drawback of using GA as the crosslinking agent, highlighting the advantages of PEDGE. 


\subsection{Stability of Selected Biosensor Designs up to Day 90}

The data in Figures 1 and 2, and Table 1, show that even biosensors incorporating the enzyme stability agent, PEI, lost a large fraction of GluOx activity from the electrode surface over a 10-day period of calibration when no crosslinker was used in their fabrication. The inclusion of a variety of crosslinking agents (Table 1) prevented loss of Glu sensitivity for at least 10 days, which is an adequate window of opportunity for a range neurochemical monitoring studies in vivo. To investigate the stability further, however, calibrations were performed on day 90 (following storage at $4{ }^{\circ} \mathrm{C}$ ) for a selection of these biosensor designs, including heat-treated and non heat-treated PEGDE, and PEG-containing biosensors.

There was a general tendency for $K_{\mathrm{M}}$ to increase by day 90 . There was no clear trend between the different crosslinkers, and the values were therefore pooled: $0.8 \pm 0.1 \mathrm{mM}(n=25)$. Compared with the crosslinker-free configuration on day 0 (see Section 3.1.1), this day 90 average represented only a marginally significant doubling $(p<0.06)$ of $K_{M}$ over 3 months of repeated calibrations and storage, and is a testament to the intrinsic stability of this surface-immobilized recombinant enzyme.

Throughout this biosensor development study, BE\% was used to highlight the contribution of the enzyme activity to the biosensor signal by normalizing the LRS response with respect to HP sensitivity. In future neurochemical applications, however, the time course of HP sensitivity for implanted biosensors cannot be determined after implantation. Only the raw output of the biosensor will be available in attempts to monitor the concentration dynamics of Glu in brain extracellular fluid. For this reason, the Glu LRS for a range of crosslinked biosensors was used to estimate their stability on day 90, and compared with the day 10 responses discussed above. There was no statistically significant change in Glu LRS sensitivity on day 90 for the two benign agents crosslinked at room temperature: PEG (from $56 \pm 9$ to $49 \pm 9 \mathrm{~mA} \cdot \mathrm{cm}^{-2} \cdot \mathrm{M}^{-1}, n=6 ; p>0.63$ ) and PEGDE (from $51 \pm 4$ to $\left.57 \pm 6 \mathrm{~mA} \cdot \mathrm{cm}^{-2} \cdot \mathrm{M}^{-1}, n=8 ; p>0.39\right)$. In contrast, for biosensors with PEGDE crosslinked at $55^{\circ} \mathrm{C}$, the LRS value halved over the same period.

In addition to changes in Glu sensitivity, the time response was also investigated over this period. For the crosslinker of choice (PEGDE, $n=10$ ) the $t_{90} \%$ values were: $0.6 \pm 0.1 \mathrm{~s}, 0.9 \pm 0.2 \mathrm{~s}$, and $1.8 \pm 0.4 \mathrm{~s}$ on days 0,10 and 90, respectively. Thus, the $\mathrm{Pt}_{\mathrm{C}} / \mathrm{PoPD} / \mathrm{PEI}_{2} / \mathrm{GluOx}_{5} / \mathrm{PEGDE}$ glutamate biosensor design displayed sub-second time responses up to day 10, and although the day 90 value was significantly greater than that for day $0(p<0.01)$, a value $<2 \mathrm{~s}$ is adequate for future LIVE applications.

\section{Conclusions}

Glutamate biosensors fabricated using both wild type and a recombinant form of GluOx were compared in terms of enzyme loading, substrate affinity and biosensor efficiency parameters, and found to be statistically equivalent. This latter, more readily available, source of GluOx can therefore be used in biosensor development without compromising analytical performance.

Comparison of a range of biosensor fabrication components showed that both the polycationic stabilizer PEI and the permselective electrosynthesized polymer PoPD enhanced the efficiency of the recombinant GluOx-based biosensor, as measured by its ability to convert the target analyte into current. Optimization of the different components yielded a biosensor of the form, $\mathrm{Pt}_{\mathrm{C}} / \mathrm{PoPD} / \mathrm{PEI}_{2} / \mathrm{GluOx}_{5}$ which, however, lost $\sim 50 \%$ of its active surface enzyme over a 10-day period. The classic crosslinking agent, GA, was applied to this biosensor design using a quenching protocol that protected the substrate affinity parameter, $K_{\mathrm{M}}$, and maintained the activity of surface GluOx. However, there were two drawbacks to GA crosslinking: the biosensor time response was slowed, and there are hazards associated with handling GA. As alternatives, therefore, both unactivated and activated PEG (PEGDE) were tested as crosslinking agents, and using a range of criteria, PEGDE was found to be superior. The resulting biosensor design $\left(\mathrm{Pt}_{\mathrm{C}} / \mathrm{PoPD} / \mathrm{PEI}_{2} / \mathrm{GluOx}_{5} / \mathrm{PEGDE}\right)$ displayed good sensitivity $(\mathrm{LOD}<0.2 \mu \mathrm{M})$, response time $\left(t_{90 \%}<1 \mathrm{~s}\right)$ and stability over a 90 -day period, making it 
an attractive candidate for future long-term in vivo electrochemical monitoring of Glu concentration dynamics in brain extracellular fluid.

Acknowledgments: The authors acknowledge financial support from the UCD School of Chemistry for RF. We thank Hitoshi Kusakabe (Enzyme-Sensor Co. Ltd., Tsukuba, Japan) for the generous gifts of wild-type and recombinant glutamate oxidase.

Author Contributions: Rochelle Ford and Robert O'Neill conceived and designed the experiments, analyzed the data, and wrote the paper; Rochelle Ford performed the experiments; Susan Quinn contributed to the broader project design, and had inputs into data analysis and MS composition.

Conflicts of Interest: The authors declare no conflict of interest.

\section{References}

1. Prodromidis, M.I.; Karayannis, M.I. Enzyme based amperometric biosensors for food analysis. Electroanalysis 2002, 14, 241-261. [CrossRef]

2. Bahadir, E.B.; Sezginturk, M.K. Applications of commercial biosensors in clinical, food, environmental, and biothreat/biowarfare analyses. Anal. Biochem. 2015, 478, 107-120. [CrossRef] [PubMed]

3. Mello, L.D.; Kubota, L.T. Review of the use of biosensors as analytical tools in the food and drink industries. Food Chem. 2002, 77, 237-256. [CrossRef]

4. Kennedy, R.T. Emerging trends in in vivo neurochemical monitoring by microdialysis. Curr. Opin. Chem. Biol. 2013, 17, 860-867. [CrossRef] [PubMed]

5. Hascup, K.N.; Hascup, E.R. Electrochemical techniques for subsecond neurotransmitter detection in live rodents. Comp. Med. 2014, 64, 249-255. [PubMed]

6. Marsman, A.; van den Heuvel, M.P.; Klomp, D.W.J.; Kahn, R.S.; Luijten, P.R.; Pol, H.E.H. Glutamate in schizophrenia: A focused review and meta-analysis of H-1-MRS studies. Schizophr. Bull. 2013, 39, 120-129. [CrossRef] [PubMed]

7. Lange, K.W.; Kornhuber, J.; Riederer, P. Dopamine/glutamate interactions in Parkinson's disease. Neurosci. Biobehav. Rev. 1997, 21, 393-400. [CrossRef]

8. Davalos, A.; Castillo, J.; Serena, J.; Noya, M. Duration of glutamate release after acute ischemic stroke. Stroke 1997, 28, 708-710. [CrossRef] [PubMed]

9. Nilsson, O.G.; Brandt, L.; Ungerstedt, U.; Saveland, H. Bedside detection of brain ischemia using intracerebral microdialysis: Subarachnoid hemorrhage and delayed ischemic deterioration. Neurosurgery 1999, 45, 1176-1184. [CrossRef] [PubMed]

10. Saveland, H.; Nilsson, O.G.; BorisMoller, F.; Wieloch, T.; Brandt, L. Intracerebral microdialysis of glutamate and aspartate in two vascular territories after aneurysmal subarachnoid hemorrhage. Neurosurgery 1996, 38, 12-19. [CrossRef] [PubMed]

11. Miele, M.; Berners, M.; Boutelle, M.G.; Kusakabe, H.; Fillenz, M. The determination of the extracellular concentration of brain glutamate using quantitative microdialysis. Brain Res. 1996, 707, 131-133. [CrossRef]

12. Shaw, P.J.; Forrest, V.; Ince, P.G.; Richardson, J.P.; Wastell, H.J. CSF and plasma amino-acid levels in motor-neuron disease-Elevation of CSF glutamate in a subset of patients. Neurodegeneration 1995, 4, 209-216. [CrossRef] [PubMed]

13. Kennedy, R.T.; Thompson, J.E.; Vickroy, T.W. In vivo monitoring of amino acids by direct sampling of brain extracellular fluid at ultralow flow rates and capillary electrophoresis. J. Neurosci. Methods 2002, 114, 39-49. [CrossRef]

14. Herman, M.A.; Jahr, C.E. Extracellular glutamate concentration in hippocampal slice. J. Neurosci. 2007, 27, 9736-9741. [CrossRef] [PubMed]

15. Palmer, A.M.; Marion, D.W.; Botscheller, M.L.; Swedlow, P.E.; Styren, S.D.; DeKosky, S.T. Traumatic brain injury-induced excitotoxicity assessed in a controlled cortical impact model. J. Neurochem. 1993, 61, 2015-2024. [CrossRef] [PubMed]

16. Marvin, J.S.; Borghuis, B.G.; Tian, L.; Cichon, J.; Harnett, M.T.; Akerboom, J.; Gordus, A.; Renninger, S.L.; Chen, T.W.; Bargmann, C.I.; et al. An optimized fluorescent probe for visualizing glutamate neurotransmission. Nat. Methods 2013, 10, 162-170. [CrossRef] [PubMed]

17. Fillenz, M. In vivo neurochemical monitoring and the study of behaviour. Neurosci. Biobehav. Rev. 2005, 29, 949-962. [CrossRef] [PubMed] 
18. Van der Zeyden, M.; Denziel, W.H.; Rea, K.; Cremers, T.I.; Westerink, B.H. Microdialysis of GABA and glutamate: Analysis, interpretation and comparison with microsensors. Pharmacol. Biochem. Behav. 2008, 90, 135-147. [CrossRef] [PubMed]

19. Rocchitta, G.; Spanu, A.; Babudieri, S.; Latte, G.; Madeddu, G.; Galleri, G.; Nuvoli, S.; Bagella, P.; Demartis, M.I.; Fiore, V.; et al. Enzyme biosensors for biomedical applications: Strategies for safeguarding analytical performances in biological fluids. Sensors 2016, 16, 780-800. [CrossRef] [PubMed]

20. O'Neill, R.D.; Lowry, J.P.; Rocchitta, G.; McMahon, C.P.; Serra, P.A. Designing sensitive and selective polymer/enzyme composite biosensors for brain monitoring in vivo. Trends Anal. Chem. 2008, 27, 78-88. [CrossRef]

21. Zhang, J.; Jaquins-Gerstl, A.; Nesbitt, K.M.; Rutan, S.C.; Michael, A.C.; Weber, S.G. In vivo monitoring of serotonin in the striatum of freely moving rats with one minute temporal resolution by online microdialysis-capillary high-performance liquid chromatography at elevated temperature and pressure. Anal. Chem. 2013, 85, 9889-9897. [CrossRef] [PubMed]

22. Crick, E.W.; Osorio, I.; Frei, M.; Mayer, A.P.; Lunte, C.E. Correlation of 3-mercaptopropionic acid induced seizures and changes in striatal neurotransmitters monitored by microdialysis. Eur. J. Pharm. Sci. 2014, 57, 25-33. [CrossRef] [PubMed]

23. Clark, J.J.; Sandberg, S.G.; Wanat, M.J.; Gan, J.O.; Horne, E.A.; Hart, A.S.; Akers, C.A.; Parker, J.G.; Willuhn, I.; Martinez, V.; et al. Chronic microsensors for longitudinal, subsecond dopamine detection in behaving animals. Nat. Methods 2010, 7, 126-129. [CrossRef] [PubMed]

24. O'Neill, R.D. Long-term monitoring of brain dopamine metabolism in vivo with carbon paste electrodes. Sensors 2005, 5, 317-342. [CrossRef]

25. Sassolas, A.; Blum, L.J.; Leca-Bouvier, B.D. Immobilization strategies to develop enzymatic biosensors. Biotechnol. Adv. 2012, 30, 489-511. [CrossRef] [PubMed]

26. Govindarajan, S.; McNeil, C.J.; Lowry, J.P.; McMahon, C.P.; O’Neill, R.D. Highly selective and stable microdisc biosensors for L-glutamate monitoring. Sens. Actuator B Chem. 2013, 178, 606-614. [CrossRef]

27. Salazar, P.; Martin, M.; O'Neill, R.D.; Roche, R.; Gonzalez-Mora, J.L. Improvement and characterization of surfactant-modified Prussian Blue screen-printed carbon electrodes for selective $\mathrm{H}_{2} \mathrm{O}_{2}$ detection at low applied potentials. J. Electroanal. Chem. 2012, 674, 48-56. [CrossRef]

28. Hamdi, N.; Wang, J.J.; Walker, E.; Maidment, N.T.; Monbouquette, H.G. An electroenzymatic L-glutamate microbiosensor selective against dopamine. J. Electroanal. Chem. 2006, 591, 33-40. [CrossRef]

29. White, S.F.; Turner, A.P.F.; Schmid, R.D.; Bilitewski, U.; Bradley, J. Investigations of platinized and rhodinized carbon electrodes for use in glucose sensors. Electroanalysis 1994, 6, 625-632. [CrossRef]

30. Sasso, S.V.; Pierce, R.J.; Walla, R.; Yacynych, A.M. Electropolymerized 1,2-diaminobenzene as a means to prevent interferences and fouling and to stabilize immobilized enzyme in electrochemical biosensors. Anal. Chem. 1990, 62, 1111-1117. [CrossRef]

31. Lowry, J.P.; O'Neill, R.D. Partial characterization in vitro of glucose oxidase-modified poly(phenylenediamine)-coated electrodes for neurochemical analysis in vivo. Electroanalysis 1994, 6, 369-379. [CrossRef]

32. Salazar, P.; Martin, M.; Roche, R.; Gonzalez-Mora, J.L.; O’Neill, R.D. Microbiosensors for glucose based on Prussian Blue modified carbon fiber electrodes for in vivo monitoring in the central nervous system. Biosens. Bioelectron. 2010, 26, 748-753. [CrossRef] [PubMed]

33. Wahono, N.; Qin, S.; Oomen, P.; Cremers, T.I.F.; de Vries, M.G.; Westerink, B.H.C. Evaluation of permselective membranes for optimization of intracerebral amperometric glutamate biosensors. Biosens. Bioelectron. 2012, 33, 260-266. [CrossRef] [PubMed]

34. Rocchitta, G.; Secchi, O.; Alvau, M.D.; Migheli, R.; Calia, G.; Bazzu, G.; Farina, D.; Desole, M.S.; O'Neill, R.D.; Serra, P.A. Development and characterization of an implantable biosensor for telemetric monitoring of ethanol in the brain of freely moving rats. Anal. Chem. 2012, 84, 7072-7079. [CrossRef] [PubMed]

35. Secchi, O.; Zinellu, M.; Spissu, Y.; Pirisinu, M.; Bazzu, G.; Migheli, R.; Desole, M.S.; O'Neill, R.D.; Serra, P.A.; Rocchitta, G. Further in vitro characterization of an implantable biosensor for ethanol monitoring in the brain. Sensors 2013, 13, 9522-9535. [CrossRef] [PubMed]

36. Arrigan, D.W.M.; Bartlett, P.N. A scanning force microscopy study of poly(phenol) films containing immobilized glucose oxidase. Biosens. Bioelectron. 1998, 13, 293-304. [CrossRef] 
37. Cosnier, S. Biomolecule immobilization on electrode surfaces by entrapment or attachment to electrochemically polymerized films. A review. Biosens. Biolelectron. 1999, 14, 443-456. [CrossRef]

38. Craig, J.D.; O'Neill, R.D. Electrosynthesis and permselective characterisation of phenol-based polymers for biosensor applications. Anal. Chim. Acta 2003, 495, 33-43. [CrossRef]

39. Calia, G.; Monti, P.; Marceddu, S.; Dettori, M.A.; Fabbri, D.; Jaoua, S.; O’Neill, R.D.; Serra, P.A.; Delogu, G.; Migheli, Q. Electropolymerized phenol derivatives as permselective polymers for biosensor applications. Analyst 2015, 140, 3607-3615. [CrossRef] [PubMed]

40. Fillenz, M.; O'Neill, R.D. Effects of light reversal on the circadian pattern of motor activity and voltammetric signals recorded in rat forebrain. J. Physiol. 1986, 374, 91-101. [CrossRef] [PubMed]

41. O'Neill, R.D.; Fillenz, M.; Albery, W.J. Circadian changes in homovanillic acid and ascorbate levels in the rat striatum using microprocessor-controlled voltammetry. Neurosci. Lett. 1982, 34, 189-193. [CrossRef]

42. Murphy, L.J. Reduction of interference response at a hydrogen peroxide detecting electrode using electropolymerized films of substituted naphthalenes. Anal. Chem. 1998, 70, 2928-2935. [CrossRef]

43. Dai, Y.Q.; Zhou, D.M.; Shiu, K.K. Permeability and permselectivity of polyphenylenediamine films synthesized at a palladium disk electrode. Electrochim. Acta 2006, 52, 297-303. [CrossRef]

44. Kirwan, S.M.; Rocchitta, G.; McMahon, C.P.; Craig, J.D.; Killoran, S.J.; O'Brien, K.B.; Serra, P.A.; Lowry, J.P.; O'Neill, R.D. Modifications of poly(O-phenylenediamine) permselective layer on Pt-Ir for biosensor application in neurochemical monitoring. Sensors 2007, 7, 420-437. [CrossRef]

45. Rothwell, S.A.; O'Neill, R.D. Effects of applied potential on the mass of non-conducting poly(ortho-phenylenediamine) electro-deposited on EQCM electrodes: Comparison with biosensor selectivity parameters. Phys. Chem. Chem. Phys. 2011, 13, 5413-5421. [CrossRef] [PubMed]

46. Killoran, S.J.; O'Neill, R.D. Characterization of permselective coatings electrosynthesized on Pt-Ir from the three phenylenediamine isomers for biosensor applications. Electrochim. Acta 2008, 53, 7303-7312. [CrossRef]

47. McMahon, C.P.; Rocchitta, G.; Serra, P.A.; Kirwan, S.M.; Lowry, J.P.; O'Neill, R.D. The efficiency of immobilised glutamate oxidase decreases with surface enzyme loading: an electrostatic effect, and reversal by a polycation significantly enhances biosensor sensitivity. Analyst 2006, 131, 68-72. [CrossRef] [PubMed]

48. McMahon, C.P.; Rocchitta, G.; Kirwan, S.M.; Killoran, S.J.; Serra, P.A.; Lowry, J.P.; O'Neill, R.D. Oxygen tolerance of an implantable polymer/enzyme composite glutamate biosensor displaying polycation-enhanced substrate sensitivity. Biosens. Bioelectron. 2007, 22, 1466-1473. [CrossRef] [PubMed]

49. Rothwell, S.A.; Kinsella, M.E.; Zain, Z.M.; Serra, P.A.; Rocchitta, G.; Lowry, J.P.; O'Neill, R.D. Contributions by a novel edge effect to the permselectivity of an electrosynthesized polymer for microbiosensor applications. Anal. Chem. 2009, 81, 3911-3918. [CrossRef] [PubMed]

50. McMahon, C.P.; Rocchitta, G.; Serra, P.A.; Kirwan, S.M.; Lowry, J.P.; O’Neill, R.D. Control of the oxygen dependence of an implantable polymer/enzyme composite biosensor for glutamate. Anal. Chem. 2006, 78, 2352-2359. [CrossRef] [PubMed]

51. Ryan, M.R.; Lowry, J.P.; Oneill, R.D. Biosensor for neurotransmitter L-glutamic acid designed for efficient use of L-glutamate oxidase and effective rejection of interference. Analyst 1997, 122, 1419-1424. [CrossRef] [PubMed]

52. Lowry, J.P.; Ryan, M.R.; O'Neill, R.D. Behaviourally induced changes in extracellular levels of brain glutamate monitored at $1 \mathrm{~s}$ resolution with an implanted biosensor. Anal. Commun. 1998, 35, 87-89. [CrossRef]

53. Arima, J.; Tamura, T.; Kusakabe, H.; Ashiuchi, M.; Yagi, T.; Tanaka, H.; Inagaki, K. Recombinant expression, biochemical characterization and stabilization through proteolysis of an L-glutamate oxidase from Streptomyces sp X-119-6. J. Biochem. 2003, 134, 805-812. [CrossRef] [PubMed]

54. Kusakabe, H.; Midorikawa, Y.; Fujishima, T.; Kuninaka, A.; Yoshino, H. Purification and properties of a new enzyme, L-glutamate oxidase, from Streptomyces sp. X-119-6 grown on wheat bran. Agric. Biol. Chem. 1983, 47, 1323-1328. [CrossRef]

55. Mikeladze, E.; Collins, A.; Sukhacheva, M.; Netrusov, A.; Csoregi, E. Characterization of a glutamate biosensor based on a novel glutamate oxidase integrated into a redox hydrogel. Electroanalysis 2002, 14, 1052-1059. [CrossRef]

56. Sirca, D.; Vardeu, A.; Pinna, M.; Diana, M.; Enrico, P. A robust, state-of-the-art amperometric microbiosensor for glutamate detection. Biosens. Bioelectron. 2014, 61, 526-531. [CrossRef] [PubMed] 
57. Vasylieva, N.; Maucler, C.; Meiller, A.; Viscogliosi, H.; Lieutaud, T.; Barbier, D.; Marinesco, S. Immobilization method to preserve enzyme specificity in biosensors: Consequences for brain glutamate detection. Anal. Chem. 2013, 85, 2507-2515. [CrossRef] [PubMed]

58. Tseng, T.T.; Chang, C.F.; Chan, W.C. Fabrication of implantable, enzyme-immobilized glutamate sensors for the monitoring of glutamate concentration changes in vitro and in vivo. Molecules 2014, 19, 7341-7355. [CrossRef] [PubMed]

59. Zhang, M.; Mullens, C.; Gorski, W. Amperometric glutamate biosensor based on chitosan enzyme film. Electrochim. Acta 2006, 51, 4528-4532. [CrossRef]

60. Khan, A.S.; Michael, A.C. Invasive consequences of using micro-electrodes and microdialysis probes in the brain. Trends Anal. Chem. 2003, 22, 503-508. [CrossRef]

61. Jaquins-Gerstl, A.; Shu, Z.; Zhang, J.; Liu, Y.; Weber, S.G.; Michael, A.C. Effect of dexamethasone on gliosis, ischemia, and dopamine extraction during microdialysis sampling in brain tissue. Anal. Chem. 2011, 83, 7662-7667. [CrossRef] [PubMed]

62. Clapp-Lilly, K.L.; Roberts, R.C.; Duffy, L.K.; Irons, K.P.; Hu, Y.; Drew, K.L. An ultrastructural analysis of tissue surrounding a microdialysis probe. J. Neurosci. Methods 1999, 90, 129-142. [CrossRef]

63. Hascup, E.R.; af Bjerken, S.; Hascup, K.N.; Pomerleau, F.; Huettl, P.; Stromberg, I.; Gerhardt, G.A. Histological studies of the effects of chronic implantation of ceramic-based microelectrode arrays and microdialysis probes in rat prefrontal cortex. Brain Res. 2009, 1291, 12-20. [CrossRef] [PubMed]

64. Rothwell, S.A.; McMahon, C.P.; O'Neill, R.D. Effects of polymerization potential on the permselectivity of poly(o-phenylenediamine) coatings deposited on Pt-Ir electrodes for biosensor applications. Electrochim. Acta 2010, 55, 1051-1060. [CrossRef]

65. Wei, W.; Song, Y.; Shi, W.; Lin, N.; Jiang, T.; Cai, X. A high sensitivity MEA probe for measuring real time rat brain glucose flux. Biosens. Biolelectron. 2014, 55, 66-71. [CrossRef] [PubMed]

66. Lowry, J.P.; McAteer, K.; El Atrash, S.S.; Duff, A.; O'Neill, R.D. Characterization of glucose oxidase-modified poly(phenylenediamine)-coated electrodes in vitro and in vivo: Homogeneous interference by ascorbic acid in hydrogen peroxide detection. Anal. Chem. 1994, 66, 1754-1761. [CrossRef]

67. Vatsyayan, P.; Bordoloi, S.; Goswami, P. Large catalase based bioelectrode for biosensor application. Biophys. Chem. 2010, 153, 36-42. [CrossRef] [PubMed]

68. Shi, G.Y.; Yamamoto, K.; Zhou, T.S.; Xu, F.; Kato, T.; Jin, J.Y.; Jin, L.T. On-line biosensors for simultaneous determination of glucose, choline, and glutamate integrated with a microseparation system. Electrophoresis 2003, 24, 3266-3272. [CrossRef] [PubMed]

69. Patel, N.G.; Erlenkotter, A.; Cammann, K.; Chemnitius, G.C. Fabrication and characterization of disposable type lactate oxidase sensors for dairy products and clinical analysis. Sens. Actuator B Chem. 2000, 67, $134-141$. [CrossRef]

70. Bunik, V.I.; Schloss, J.V.; Pinto, J.T.; Gibson, G.E.; Cooper, A.J.L. Enzyme-catalyzed side reactions with molecular oxygen may contribute to cell signaling and neurodegenerative diseases. Neurochem. Res. 2007, 32, 871-891. [CrossRef] [PubMed]

71. Reyes De Corcuera, J.I.; Cavalieri, R.P.; Powers, J.R. Improved platinization conditions produce a 60-fold increase in sensitivity of amperometric biosensors using glucose oxidase immobilized in poly-o-phenylenediamine. J. Electroanal. Chem. 2005, 575, 229-241. [CrossRef]

72. Chirizzi, D.; Malitesta, C. Potentiometric urea biosensor based on urease immobilized by an electrosynthesized poly(o-phenylenediamine) film with buffering capability. Sens. Actuator B Chem. 2011, 157, 211-215. [CrossRef]

73. Chen, W.; Cai, S.; Ren, Q.Q.; Wen, W.; Zhao, Y.D. Recent advances in electrochemical sensing for hydrogen peroxide: A review. Analyst 2012, 137, 49-58. [CrossRef] [PubMed]

74. Deng, C.Y.; Li, M.R.; Xie, Q.J.; Liu, M.L.; Tan, Y.M.; Xu, X.H.; Yao, S.Z. New glucose biosensor based on a poly(o-phenylendiamine)/glucose oxidase-glutaraldehyde/Prussian blue/Au electrode with QCM monitoring of various electrode-surface modifications. Anal. Chim. Acta 2006, 557, 85-94. [CrossRef]

75. Hamdan, S.K.; Mohd Zain, A. In vivo Electrochemical Biosensor for Brain Glutamate Detection: A Mini Review. Malays. J. Med. Sci. 2014, 21, 12-26. [PubMed]

76. McMahon, C.P.; O'Neill, R.D. Polymer-enzyme composite biosensor with high glutamate sensitivity and low oxygen dependence. Anal. Chem. 2005, 77, 1196-1199. [CrossRef] [PubMed] 
77. Rahman, M.A.; Kwon, N.H.; Won, M.S.; Choe, E.S.; Shim, Y.S. Functionalized conducting polymer as an enzyme-immobilizing substrate: An amperometric glutamate microbiosensor for in vivo measurements. Anal. Chem. 2005, 77, 4854-4860. [CrossRef] [PubMed]

78. Varma, S.; Yigzaw, Y.; Gorton, L. Prussian blue-glutamate oxidase modified glassy carbon electrode: A sensitive L-glutamate and $\beta$ - $N$-oxalyl- $\alpha, \beta$-diaminopropionic acid ( $\beta$-ODAP) sensor. Anal. Chim. Acta 2006, 556, 319-325. [CrossRef]

79. Ammam, M.; Fransaer, J. Highly sensitive and selective glutamate microbiosensor based on cast polyurethane/AC-electrophoresis deposited multiwalled carbon nanotubes and then glutamate oxidase/electrosynthesized polypyrrole/Pt electrode. Biosens. Bioelectron. 2010, 25, 1597-1602. [CrossRef] [PubMed]

80. Windmiller, J.R.; Valdes-Ramirez, G.; Zhou, N.; Zhou, M.; Miller, P.R.; Jin, C.; Brozik, S.M.; Polsky, R.; Katz, E.; Narayan, R.; Wang, J. Bicomponent microneedle array biosensor for minimally-invasive glutamate monitoring. Electroanalysis 2011, 23, 2302-2309. [CrossRef]

81. Migneault, I.; Dartiguenave, C.; Bertrand, M.J.; Waldron, K.C. Glutaraldehyde: behavior in aqueous solution, reaction with proteins, and application to enzyme crosslinking. Biotechniques 2004, 37, 790-802. [PubMed]

82. Turner, A.P.F.; Karube, I.; Wilson, G.S. Biosensors: Fundamentals and Applications; Oxford University Press: New York, NY, USA, 1987.

83. Zhang, M.G.; Mullens, C.; Gorski, W. Chitosan-glutamate oxidase gels: Synthesis, characterization, and glutamate determination. Electroanalysis 2005, 17, 2114-2120. [CrossRef]

84. Barsan, M.M.; Klincar, J.; Batic, M.; Brett, C.M.A. Design and application of a flow cell for carbon-film based electrochemical enzyme biosensors. Talanta 2007, 71, 1893-1900. [CrossRef] [PubMed]

85. Maalouf, R.; Chebib, H.; Saikali, Y.; Vittori, O.; Sigaud, M.; Jaffrezic-Renault, N. Amperometric and impedimetric characterization of a glutamate biosensor based on Nafion ${ }^{\circledR}$ and a methyl viologen modified glassy carbon electrode. Biosens. Bioelectron. 2007, 22, 2682-2688. [CrossRef] [PubMed]

86. Zalipsky, S. Chemistry of polyethylene-glycol conjugates with biologically-active molecules. Adv. Drug Deliv. Rev. 1995, 16, 157-182. [CrossRef]

87. Gregg, B.A.; Heller, A. Redox polymer-films containing enzymes. 2. Glucose-oxidase containing enzyme electrodes. J. Phys. Chem. 1991, 95, 5976-5980. [CrossRef]

88. Vasylieva, N.; Barnych, B.; Meillerd, A.; Maucler, C.; Pollegioni, L.; Lin, J.S.; Barbier, D.; Marinesco, S. Covalent enzyme immobilization by poly(ethylene glycol) diglycidyl ether (PEGDE) for microelectrode biosensor preparation. Biosens. Bioelectron. 2011, 26, 3993-4000. [CrossRef] [PubMed]

89. Cragg, S.J.; Rice, M.E. DAncing past the DAT at a DA synapse. Trends Neurosci. 2004, 27, 270-277. [CrossRef] [PubMed]

90. Sabatini, B.L.; Regehr, W.G. Timing of neurotransmission at fast synapses in the mammalian brain. Nature 1996, 384, 170-172. [CrossRef] [PubMed]

(C) 2016 by the authors; licensee MDPI, Basel, Switzerland. This article is an open access article distributed under the terms and conditions of the Creative Commons Attribution (CC-BY) license (http://creativecommons.org/licenses/by/4.0/). 